\title{
Saudi EFL Learners' Response to Different Grammar Tasks
}

\author{
Dr. Sami M. Alenezi \\ University of Central Lancashire
}

\begin{abstract}
This study examines intermediate level adult EFL students in Saudi Arabia, and the effectiveness of task-based learning in relation to their understanding of English grammar. The students were given three different tasks related to negative adverbs, designed to help them learn past-tense verb forms in English. There were three groups of 20 students, all of whom were learning at the same level. The groups were:
\end{abstract}

- Selected response group ( $S R G, n=20)$

- Constrained constructed response group $(C C R, n=20)$

- Storytelling group (FRG, $\mathrm{n}=20)$

Each group was given a pre-test to determine their level before the tasks, a test immediately after, and a delayed test. The selected response group (SRG) performed best on the tests, demonstrating the effectiveness of taskbased teaching in grammar acquisition. Students were chosen at random for an interview, in which their grammar knowledge was assessed. This produced results that mirrored those of the tests. It was also clear that the kinds of tasks chosen by teachers had an impact on the effectiveness of their lessons. This study provides EFL teachers with vital information they can use in learning design and lesson planning and gives EFL students information they can use to support their own learning.

Keywords: SLA, ELT, tasks, explicit instruction, grammar teaching

Date of Publication: 30.05.2018

DOI: $10.24297 / j a l . v 9 i 1.7099$

ISSN: 2348-3024

Volume: 9 Issue: 01

Journal: Journal of Advances in Linguistics

Website: https://cirworld.com

This work is licensed under a Creative Commons Attribution 4.0 International License. 


\section{INTRODUCTION}

\subsection{Introduction}

The teaching of grammar is "a necessary component of any language teaching program" (Rutherford, 1987, p.9). During the 1970s, formal grammar teaching fell out of favour in EFL classrooms, replaced by communicative methodology. But it has become clear in more recent years, partly as a result of academic research, that it is important for students to have an understanding of grammatical structures. Current practice is evolving to include the teaching of grammar within communicative methodologies.

Task-based grammar teaching uses real-life tasks designed to help students use their grammar knowledge in a realistic way, in interactions that mirror those they will encounter in day-to-day life. Ellis (2003) said of taskbased teaching: "It is clear to me that if learners are to develop the competence they need to use a language easily and effectively in the kinds of situations they meet outside the classroom they need to experience how language is used as a tool for communicating inside it".

This study examines how task-based teaching helps students to learn and seeks to identify the kinds of tasks that are most effective. The choice of task will naturally influence the way in which students learn and what they learn. Tasks can be chosen specifically because they are designed to fill gas in students' learning. This is termed "structure trapping". Structures can be used to a greater or lesser extent to help students finish tasks (Loschky \& Bley-Vroman,1993).

Reinders (2008) gives definitions for different elements of task-based teaching. "Task naturalness" is the way in which grammar structures come up naturally while a task is being carried out. "Task utility" is the use of grammar structures to finish a task in cases where this is not vital to completion. "Task essentialness" is the use of a grammar structure to finish a task. This is not easy to do.

For students to be successful, they need to spend considerable time learning and practising their skills. According to Reinders (2008, p. 311) "There is no guarantee that a task in which a structure naturally occurs will, by itself, trigger the initial acquisition of that structure, even if the structure is modelled, primed, or otherwise 'taught' in the task". That is, task based learning helps give students the ability to use their pre-existing knowledge more easily. It does not necessarily lead to the acquisition of new knowledge.

Willis (1996) states that teachers should not seek to direct students' learning but should understanding what a student needs to learn in order to carry out a task. They can do this by focusing on relevant elements of the task when they are outlining it to the student. Studies have looked at the differences in effectiveness between implicit and explicit instructions but have not done so in the context of task-based learning.

This study examines how students learn English grammar, specifically past tense verbs, across three different types of tasks. Further studies are required to examine the role of instruction in students' ability to learn grammar via task-based learning. Studies should also examine how students feel about task-based learning and about specific tasks they have undertaken.

\subsection{Research Questions}

This study's objective is to determine whether EFL students' English language ability is affected by their participation in particular classroom tasks. Their ability was assessed both immediately after they carried out a task, and later.

The research questions are:

1) Is grammar acquisition improved in EFL students as a result of task-based learning? 
2) Which task is the most effective?

\subsection{Methodology}

\subsection{Participants}

The participants in this study were 60 Saudi EFL students. They were undergraduate students and were chosen from across three EFL classes. All were in their second year at university, studying a variety of subjects. The three classes were each allocated a task at random.

\subsection{Instruments}

The three tasks used were: gap-filling, storytelling and multiple-choice.

\subsection{Procedures}

The study was entirely confidential, with students given an assurance that their participation and results would not affect their course results at all. Before the study could begin, permission was sought from teachers and the EFL department. The study took three weeks, with thirty minutes of each of the students' classes given over to it.

The students were given a test at the start of the study to ascertain their existing level of knowledge. This same test was given again immediately after they had undertaken tasks, and then later on. With each testing, the order of questions was altered. The teacher/researcher gave the students explicit grammar instruction using each of the three types of task: storytelling, multiple-choice and gap-filling. The three groups were randomly allocated to one of the three tasks.

For the purposes of the study, four texts were used. Each of them included three target grammar structures. The students were given explicit instructions and then given 20 minutes to work on them.

\subsubsection{Selected-Response Group (SRG)}

This group was given a selected response, or multiple-choice, task. The task asked students to "choose the correct response from a range of alternatives" (Norris and Ortega, 2000, p. 440). It measured students' perception of particular grammatical structures. All grammar structures used in the test were past verb forms. A selected response test is a dependable way of gathering metalinguistic data, and it can ensure concentration on the particular forms being studied (Tavakoli \& Foster, 2008; 2011). Multiple-choice tests can be defined as metalinguistic knowledge tests that are used for level two meta-analysis (Norris and Ortega, 2000).

A multiple-choice test is made up of statements that can have more than one answer. They are simple tests to use, create and administer (Roediger \& Marsh, 2005; Hickey, 2014). They are also efficient (Hickey, 2014). In common with gap-filling tests, they are an effective way of ascertaining whether students have learned particular grammar forms (Ellis et al., 2009).

\subsubsection{Constrained Constructed Response Group (CCRG)}

Constrained constructed response, or gap-filling, was used for this group. As with the SR group, this group was given nine test questions. The task used texts that had originally included the grammar forms that had been taught. For the test, these grammar forms were removed, and students were asked to fill in the blanks. They were given the infinitive form of the verb in each case as an aide.

Gap-filling tests are an effective way to examine learning ability in level two students. Doughty (2002) provides a list of tests that can be used to determine level two students' knowledge. They include selected response (SR), 
free constructed response (FCR), and controlled constructed response (CCR) (i.e. gap-filling). Ellis et al. (2009) identify that all three of these tests:

1) Determine how far students use of language is either free or controlled

2) Determine levels of comprehension and competent use of grammar.

Norris \& Ortega (2000) argue that all three types of tests can have a considerable impact.

\subsubsection{Free Constructed Response Group (FCRG)}

The FCRG or storytelling task was given to the third group. As with the other tests, it looked at past verbs and was audio recorded. This task gave students pictures set out to tell a story, with events in chronological order. Students were asked to work through the story and the pictures, using grammar as needed. The pictures were prompts, some of which required students to come up with detailed descriptions, others with simple sentences or words (Brown and Abeywickrama, 2010).

A storytelling task gives level two students the freedom to construct their own responses, unguided (Norris \& Ortega, 2000). It is thought by some to be a highly effective test of ability for these students, as it examines their use of English in real-world interactions (Ellis, 2005). Some scholars believe that gap-filling tests are more effective (Norris \& Ortega, 2000). However, it is certain that storytelling or CFR tests are good, well-established and effective (Norris \& Ortega, 2000; Leeman, 2003; Ellis 2005).

\subsection{Results}

The variance (ANOVA) between the three study groups was analysed. Their results in the initial test, done before the study took place, were compared $[F(2,33)=0.512, p=0.681]$. All three groups had similar results $[F(2,33)$ $=0.512, p=0.681]$. All three demonstrated higher ability in $S R(M=5.61, S D=1.122)$ than $C C R(M=4.96, S D$ $=1.721)$ and FCR $(M=4.89, S D=1.653)$.

\begin{tabular}{|l|l|l|l|}
\hline Group & Mean & Std. Deviation & Significance \\
\hline SR & 8.61 & 3.122 & \\
\cline { 1 - 2 } CCR & 7.96 & 3.721 & \multirow{2}{*}{0.681} \\
\cline { 1 - 3 } & 8.89 & 3.653 & \\
\hline
\end{tabular}

Table 1: The results of the initial test for the SR, CCR and FCR groups.

After the students had carried out the study's tasks, they were tested again. This test showed a small increase in the students' abilities. There was no significant difference between each group.

\begin{tabular}{|l|l|l|l|}
\hline Group & Mean & Std. Deviation & Significance \\
\hline SR & 8.90 & 3.121 & \multirow{2}{*}{0.542} \\
\hline CCR & 8.32 & 3.427 & \\
\cline { 1 - 3 } FCR & 8.74 & 3.901 & \\
\hline
\end{tabular}

Table 2: The results of the post-study test for the SR, CCR and FCR groups 
The students were tested again some time later, using the Tukey HSD Post Hoc Test. In this test, there was a clear difference between the groups, with the SR (multiple-choice) group performing better than the other groups. When the SR and CCR groups ( $p .=0.531)$ only were compared, there was little difference apparent. Similarly, comparing only the SR and FCR groups ( $\left.p_{.}=0.581\right)$ showed little difference. The same was true of comparing the FCR and CCR groups ( $p .=0.540)$.

\begin{tabular}{|c|c|c|c|c|c|c|}
\hline \multirow[b]{2}{*}{ (I) Group } & \multirow[b]{2}{*}{ (J) Group } & \multirow{2}{*}{$\begin{array}{l}\text { Mean Difference (I- } \\
\text { J) }\end{array}$} & \multirow[b]{2}{*}{ Std. Error } & \multirow[b]{2}{*}{ Sig. } & \multicolumn{2}{|c|}{ 95\% Confidence Interval } \\
\hline & & & & & Lower Bound & Upper Bound \\
\hline SR & CCR & .58 & .48 & 0.531 & -.70 & 1.70 \\
\hline SR & FCR & .16 & .48 & 0.581 & -.30 & 1.30 \\
\hline FCR & $C C R$ & .42 & .48 & 0.540 & -.60 & 1.60 \\
\hline
\end{tabular}

Table 3: The descriptive statistics results of the post hoc test

\subsection{Discussion and Conclusion}

The study set out to determine whether a task-based learning approach could lead to increased understanding of grammatical structures among EFL students. The results show that all three of the study groups scored higher on the post-test than they did on the pre-test. They also showed that the SR group, given a multiple-choice task, performed better than either of the other groups in the post-test. Therefore, we can conclude that the use of explicit, direct instruction with EFL learners, alongside a multiple-choice task, leads to improved understanding of grammar structures by students.

The delayed post-test was designed to establish whether students retained the grammar knowledge learned during the task. It was assumed that the CCR group would perform least well in the delayed post-test, with the FCR group performing better.

The study indicates that while multiple-choice tasks are more effective than other tasks in helping students learn and retain understanding of grammar, storytelling and gap-filling tasks are also beneficial.

The study also asked whether students' assumptions about the effectiveness of each type of task were borne out by the results of the test. Interviews were carried out with some students to establish their views. These interviews showed that the students believed SR tasks to be the most effective.

\section{REFERENCES}

Brown, H. D. \& Abeywickrama, P. (2010). Language assessment: Principles and classroom practices. (2nd Ed.). White Plains, NY: Pearson Education, Inc.

Doughty, C. J. (2003). The handbook of second language acquisition. Malden, MA: Blackwell Publishers.

Ellis, R. (2003). Task-based language learning and teaching. Oxford: Oxford University Press.

Ellis, R. (2005). Instructed Second Language Acquisition A Literature Review Report to The Ministry of Education. New Zealand: Auckland Uniservices Limited.

Ellis, R., Loewen, S., Elder, C., Erlam, R., Philp, J., \& Reinders, H. (2009). Implicit and explicit knowledge in Second language learning, testing and teaching. United Kingdom: Channel View Publications. 
Hickey, D. (2014). Selected response test items Retrieved from

https://www.youtube.com/watch?v=Hnc0swrRX6A\&nohtml5=False

Leeman, J. (2003). RECASTS AND SECOND LANGUAGE DEVELOPMENT: Beyond Negative Evidence. Studies in Second Language Acquisition, 25(1), 37-63. doi:10.1017/S0272263103000020

Loschky, L., \& Bley-Vroman, R. (1993). Grammar and task-based methodology. In G. Crookes \& S. Gass (Eds.), Tasks and language learning (pp. 123-163). Clevedon, UK: Multilingual Matters.

Norris, J., \& Ortega, L. (2000). Effectiveness of L2 Instruction: A research synthesis and quantitative meta-analysis. Language Learning, 50, 417-428.

Reinders, H. (2008). The what, why, and how of language advising. MexTESOL, 32(2).

Roediger, H. L., III, \& Marsh, E. J. (2005). The positive and negative consequences of multiple-choice testing. Journal of Experimental Psychology: Learning, Memory, and Cognition, 31(5), 1155-1159. doi:10.1037/02787393.31.5.1155

Rutherford, W. (1987). Second language grammar learning and teaching. New York: Longman.

Tavakoli, P., \& Foster, P. (2008). Task design and Second language performance: The effect of narrative type on Learner output. Language Learning, 58(2), 439-473. doi:10.1111/j.1467-9922.2008.00446.x

Tavakoli, P., \& Foster, P. (2011). Task design and Second language performance: The effect of narrative type on Learner output. Language Learning, 61, 37-72. doi:10.1111/j.1467-9922.2011.00642.x

Willis, J. (1996). A Framework for Task-based Learning. Harlow: Addison Wesley Longman. 